\title{
PODSUMOWANIE PIERWSZEGO PIECIOLECIA AKTYWNOŚCI PROFILU FACEBOOK BIBLIOTEKI NAUKOWEJ PAU I PAN W KRAKOWIE
}

Jedną z inicjatyw promujących zbiory Biblioteki Naukowej PAU i PAN w Krakowie jest jej profil w serwisie Facebook ${ }^{1}$. Założony 1 lipca 2015 r. rozwija się stopniowo, zdobywając kolejnych fanów. Tegoroczna pandemia COVID-19 i związane z nią zamknięcie Czytelni Biblioteki na ponad trzy miesiące (marzecczerwiec 2020) zmotywowały nas do zdefiniowania na nowo tej formy kontaktu z naszymi czytelnikami i obserwatorami.

W swoich początkach profil Biblioteki pełnił przede wszystkim rolę informacyjna. W trakcie prowadzonych w latach 2015-2016 prac nad nową stroną internetową stanowił on główny kanał publikacji ogłoszeń. Funkcja tablicy informacyjnej pozostaje niezwykle istotna. Profil jest podstawowym źródłem informacji o zmianach zasad funkcjonowania biblioteki - przede wszystkim godzin otwarcia, ofertach pracy, istotnych wydarzeniach, których Biblioteka jest organizatorem, nowych pozycjach w zbiorach bibliotecznych (nowościach wydawniczych oraz różnych darach), projektach badawczych i wystawach oraz o nowych publikacjach wydawanych przez Bibliotekę bądź prezentujących Jej zbiory.

Stopniowo na profilu Biblioteki zaczęły pojawiać się też posty upamiętniające różne wydarzenia: święta oficjalne i nieoficjalne, popularne imieniny, rocznice historyczne itp. Staramy się przy tym wykorzystywać reprodukcje naszych zbiorów. Najczęściej udostępniane są zbiory ikonograficzne zdigitalizowane w ramach projektu PAUart (wolny dostęp za pośrednictwem portalu www. pauart.pl), ale uwzględniamy też nasze druki i rękopisy. Z czasem zaczęliśmy też eksperymentować z różnorodnymi sposobami prezentowania naszych zasobów. Pojawiły się pierwsze albumy i filmy. W latach 2017-2020 w tej formie prezentowaliśmy najciekawsze nowości wydawnicze dostępne w Bibliotece oraz kalendarze ilustrowane rycinami z naszej kolekcji starych druków (w 2017 przedstawienia ptaków François-Nicolasa Martineta, w 2018 kostiumy z Magazzino delle mode), z Gabinetu Rycin (w 2019 ryciny autorstwa prof. Krzysztofa Skórczewskiego ofiarowane nam przez Autora) oraz zbiorów kartograficznych (w 2020 mapy oraz skorelowane z nimi fotografie z Fototeki Lanckorońskich).

${ }^{1}$ Główną redaktorką profilu była do końca grudnia 2020 Julia Czapla. Wraz z nią współtworzą go dr Karolina Grodziska (od 2015) i dr Agnieszka Fluda-Krokos (od 2019). 
W 2019 przyłączyliśmy się do akcji \#colorourcollections ${ }^{2}$. Materiały filmowe są najrzadziej wykorzystywaną formą prezentacji naszych zbiorów. Za pośrednictwem tego medium reklamowaliśmy w 2015 nasz projekt konserwacji rękopisów ze zbiorów Hieronima Łopacińskiego ${ }^{3}$, udostępniliśmy przygotowany przez Telewizję Polską program „Książki pod specjalnym nadzorem” zrealizowany w naszej Bibliotece w 20154, a w 2020 zaprezentowaliśmy kolekcję filmów pokazujących specyfikę poszczególnych działów Biblioteki Naukowej PAU i PAN w Krakowie.

Zamknięcie Czytelni Biblioteki wiosną 2020 stało się dla nas okazją do zorganizowania kilkunastu akcji promujących nasze zbiory i działalność. W ramach ogólnopolskiej inicjatywy \#NieZostawiamCzytelnika ${ }^{5}$ przedstawialiśmy sylwetki naszych ofiarodawców XIX-wiecznych, specyfikę różnych działów Biblioteki, nasze najcenniejsze bądź najciekawsze zbiory, a także ofertę naszych ulubionych zasobów i narzędzi internetowych. W oczekiwaniu na tegoroczną wystawę „Rośliny i zwierzęta” zorganizowaną we współpracy z Międzynarodowym Centrum Kultury w Krakowie przypominaliśmy efekty naszej 25-letniej współpracy wystawienniczej. W maju, z okazji XVII Ogólnopolskiego Tygodnia Bibliotek, opublikowaliśmy prezentacje naszych działów i ich zbiorów. W tym okresie zrezygnowaliśmy też z akcji publikowania mało wykorzystywanych informacji o nowościach wydawniczych w naszych zbiorach.

Po ponownym otwarciu Czytelni w lipcu 2020 skupiliśmy się na prezentowaniu naszych zbiorów, zarówno pod pretekstem ważnych rocznic czy imienin, jak i w cyklach prezentujących zasoby Zbiorów Specjalnych i Gabinetu Rycin. W przyszłym roku planujemy też zacieśnić współpracę z profilem portalu PAUart.

W ciagu ostatnich pięciu lat na profilu Biblioteki zostało opublikowanych 1311 wpisów, w większości oryginalnych ${ }^{6}$. Staramy się, by możliwie dużo naszych wpisów było opatrzonych ilustracjami. Poza postami zawierającymi jedno

${ }^{2}$ Inicjatywa zapoczątkowana przez bibliotekę The New York Academy of Medicine w 2016 ma na celu popularyzację zbiorów ikonograficznych bibliotek poprzez zachęcanie internautów do kolorowania reprodukcji rycin i udostępniania ich w mediach społecznościowych.

3 Projekt zrealizowany pod kierownictwem dr Elżbiety Knapek, współfinansowany ze środków Ministerstwa Kultury i Dziedzictwa Narodowego, obejmował konserwację zbioru łacińskich kazań i żywotów świętych, spisanego w Krakowie w połowie XV w. oraz XVIII-wiecznego zbioru inwektyw i ubolewań, zob. http://biblioteka.pau.krakow.pl/dzialalnosc/projekty/konserwacje (dostęp: 1.10 .2020$)$.

${ }^{4}$ Film dostępny pod adresem: https://www.facebook.com/665207616912245/videos/70958 6412474365/ (dostęp: 1.10.2020).

5 Inicjatywa Stowarzyszenia Bibliotekarzy Polskich mająca „,na celu promowanie dostępu do kultury online w czasach pandemii" (\#NieZostawiamCzytelnika - akcja SBP dla bibliotekarzy [w:] SBP. Ogólnopolski Portal Bibliotekarski, 17.03.2020, http://www.sbp.pl/artykul/?cid=22200 (dostęp: 1.10.2020).

${ }^{6}$ Cytowane w dalszej części artykułu dane statystyczne przedstawiają stan na 30 września $2020 \mathrm{r}$. 
lub kilka zdjęć część naszych materiałów publikujemy w formie albumów, które są dla nas metodą porządkowania starszych ilustracji. W sumie w 60 albumach znajduje się 2201 zdjęć. Staramy się, by nasze wpisy koncentrowały się wokół naszych zbiorów, promowały je zarówno wśród naszych stałych czytelników, jak i wśród niekorzystających na co dzień ze zbiorów Biblioteki obserwatorów, w nadziei, że zachęci ich to do skorzystania z naszych zasobów na miejscu.

Do października 2020 profil Biblioteki Naukowej PAU i PAN w Krakowie posiadał 1107 użytkowników i 1192 obserwatorów. Większość z nich to goście, uważnie śledzący nasze wpisy, jednak wchodzący w sporadyczne interakcje z nimi. Są też użytkownicy bardzo zaangażowani, regularnie dający polubienia i udostępniający nasze posty, oraz uważni czytelnicy naszego profilu komentujący wpisy.

Nasi obserwatorzy to przede wszystkim osoby w wieku 25-54 (76\%), pozostałe grupy wiekowe reprezentowane są w mniejszym stopniu, generalnie pokrywającym się z aktywnością zawodową i kompetencjami cyfrowymi różnych grup odbiorców. Większość z nich stanowią mieszkańcy Krakowa (46\%) oraz innych polskich miast (m.in. Warszawa - 18\%, Wrocław, Katowice, Poznań - po 3\%, Łódź, Lublin, Toruń - po 2\%; w sumie osoby deklarujące Polskę jako kraj pochodzenia stanowią 87\% fanów naszego profilu). Wśród naszych zagranicznych obserwatorów dominują Ukraińcy ( $25 \%$ użytkowników zagranicznych, 3\% ogólnej liczby użytkowników). Liczną grupę naszych obserwatorów stanowią też mieszkańcy Litwy i Białorusi (po 11\% użytkowników zagranicznych, po ok. 1\% ogólnej liczby). Tę popularność wśród naszych wschodnich sąsiadów można chyba $\mathrm{z}$ dużą dozą prawdopodobieństwa powiązać z profilem naszej kolekcji, w której poczesne miejsce zajmują materiały dotyczące historii ziem dawnej Rzeczypospolitej. Nieco mniej obserwatorów mamy w krajach Europy Zachodniej. Wielką Brytanię jako kraj pochodzenia deklaruje $8 \%$ naszych zagranicznych użytkowników (ok. 1\% ogólnej liczby użytkowników), Niemcy - 5\% (ok. 1\% ogólnej liczby użytkowników), w innych krajach popularność szacuje się na poziomie $1-3 \%$ użytkowników zagranicznych.

Podobnie jak w wielu innych bibliotekach i instytucjach kulturalnych obserwatorzy profilu rzadko są czytelnikami korzystającymi z naszych zasobów „realnych”, choć wśród naszych fanów zdarzają się też użytkownicy Biblioteki. Dodatkowo, 41 spośród naszych obserwatorów (3\%) stanowią strony innych instytucji polskich i zagranicznych (m.in. biblioteki, archiwa, muzea i instytucje kulturalne, z którymi współpracujemy) oraz powiązane profile innych agend Polskiej Akademii Umiejętności i Polskiej Akademii Nauk (PAU i PAN, Archiwum Nauki PAU i PAN w Krakowie, portal PAUart oraz Biblioteka Polska w Paryżu).

Obserwatorzy i fani naszego profilu chętnie czytają nasze posty. Najwięcej zainteresowania budzą posty prezentujące nasze zbiory, generalnie to one zyskują najwięcej „wejść” i skłaniają do reakcji - polubień i udostępnień, rzadziej 


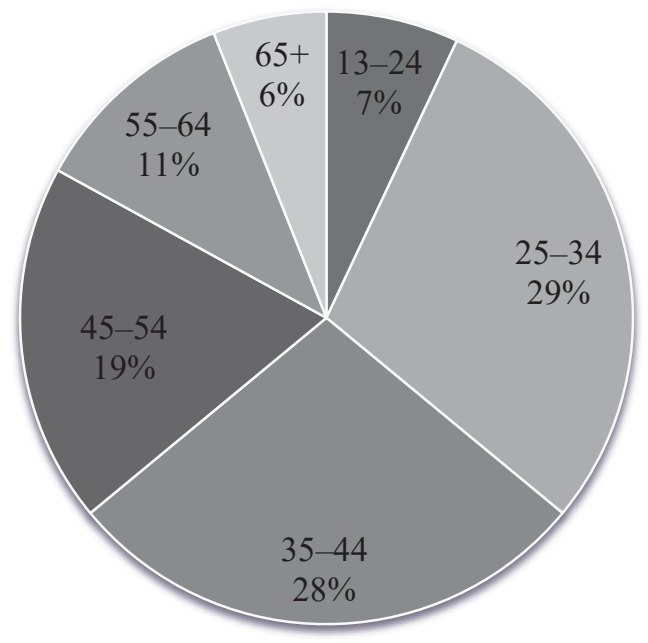

Obserwatorzy profilu według grup wiekowych

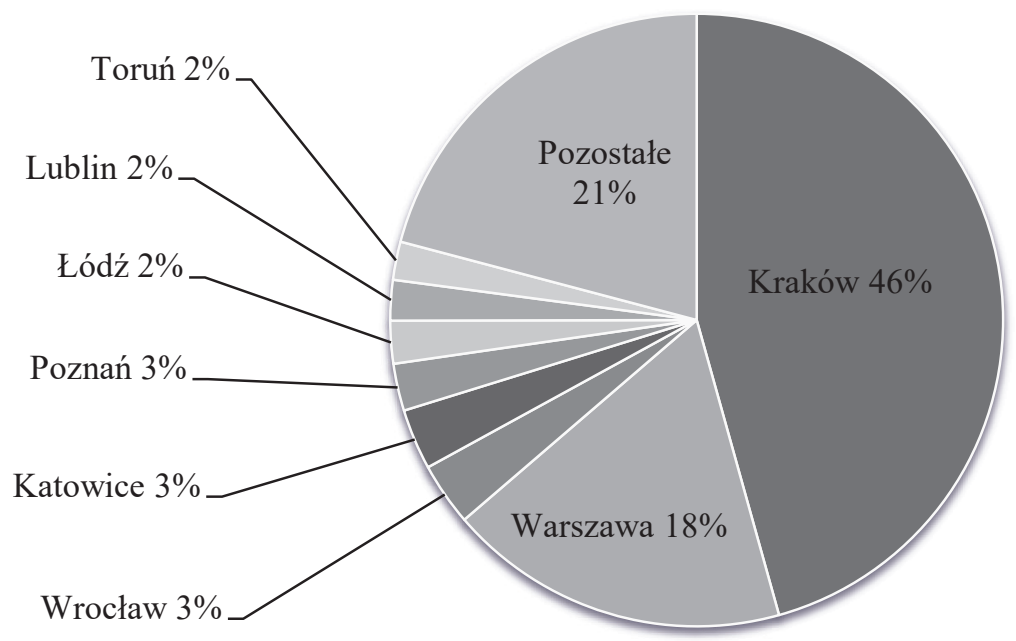

Obserwatorzy profilu według miast Polski 


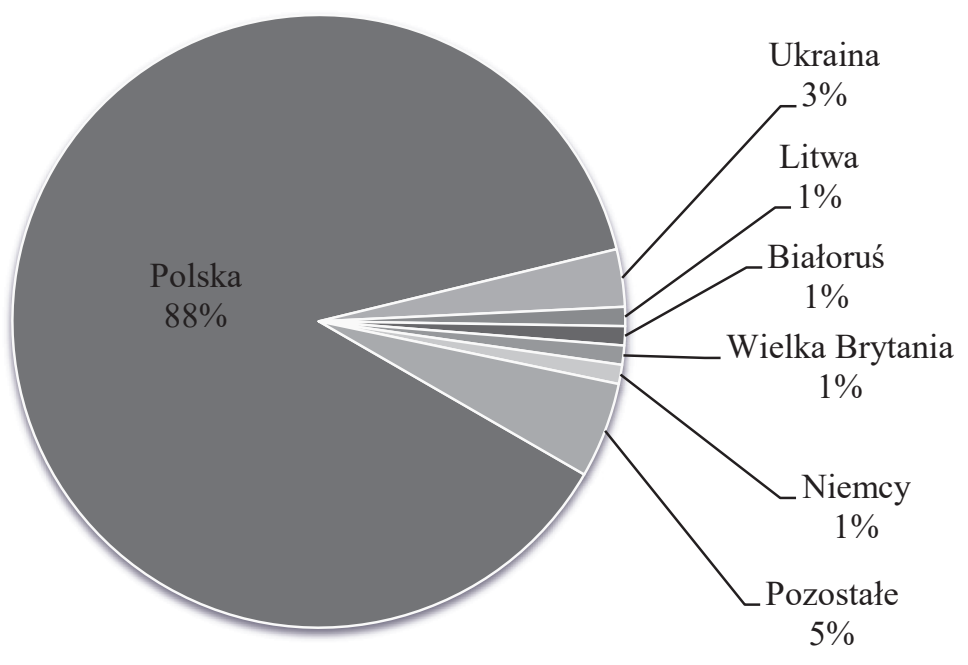

Obserwatorzy profilu według krajów

komentarzy. Uzyskują one zasięg od kilkuset do kilku tysięcy zainteresowanych? Do naszych rekordzistów należą tegoroczne wpisy z okazji Dnia Kawii Domowej (16 lipca) i Światowego Dnia Kawy (29 września), które zainteresowały ponad 7000 osób. Spore zainteresowanie budzą też informacje związane z wydarzeniami organizowanymi i współorganizowanymi przez Bibliotekę, m.in. o wystawach przygotowywanych z Międzynarodowym Centrum Kultury i Archiwum Nauki PAN i PAU w Krakowie, konferencjach organizowanych w Polskiej Akademii Umiejętności, naszej obecności (w ramach stoiska Wydawnictwa PAU) na Targach Książki w Krakowie czy naszym udziale w zeszłorocznej Nocy Bibliotek. Mimo że nasi użytkownicy niezbyt często deklarowali udział w wydarzeniach, chętnie śledzili relacje filmowe i fotograficzne publikowane na naszym profilu.

Fani, którzy są też użytkownikami naszej Biblioteki, czerpią stąd informacje o zmianach $w$ zasadach funkcjonowania Biblioteki. Z rozmów prowadzonych z czytelnikami wiemy, że właśnie z Facebooka Biblioteki dowiadywali się o zmianach godzin otwarcia czytelni, wprowadzeniu nowego regulaminu i dodatkowych obostrzeń związanych z reżimem sanitarnym obowiązującym w czasie pandemii. Dla naszych stałych bywalców profil jest też okazją do poszerzenia wiedzy o naszych zasobach oraz o możliwościach korzystania z Biblioteki. Za jego pośrednictwem poznają nasze nowe publikacje oraz nowe kanały udostępniania informacji o zbiorach, np. dzięki wpisom o rozpoczęciu wprowadzania do katalogu elektronicznego rękopisów oraz o umożliwieniu elektronicznego zamawiania materiałów do czytelni.

7 Biblioteka nie korzysta z płatnej promocji ani reklam. 
Zamieszczane na naszym profilu informacje o ofertach pracy także cieszą się sporą popularnością wśród użytkowników Facebooka. Ich odbiorcami nie są jednak tylko nasi regularni obserwatorzy. Generalnie, informacje te kierowane są do osób spoza tego grona i trafiają do nich przede wszystkim za pośrednictwem profili powiazzanych z nami instytucji oraz poprzez profile naszych czytelników i pracowników.

Mamy nadzieję, że w następnych latach nasz profil nadal będzie się rozwijał, zdobywając nowych czytelników i obserwatorów, co w dłuższej perspektywie przełoży się na większe zainteresowanie naszymi zbiorami.

opracowała Julia Czapla 